\title{
Research into Veterinary Aspects of Food Safety and Quality, and Animal Production Health at the University of Veterinary and Pharmaceutical Sciences in Brno
}

\author{
V. VEČEREK \\ University of Veterinary and Pharmaceutical Sciences in Brno, Czech Republic
}

\begin{abstract}
Food safety and quality and animal production health have recently become major topics of veterinary research and the focus of several national, European and international grant agencies. Since 2005, the University of Veterinary and Pharmaceutical Sciences in Brno has been conducting two major projects in these areas. Both projects contribute to enhancing the quality of research at the university, and some results have been published in peer-reviewed international scientific journals included in the Citation Index database. Papers have also been published in Acta Veterinaria Brno, and those submitted for publication in 2007 form the basis for a special supplement dealing with veterinary aspects of food safety and quality, and animal production health.
\end{abstract}

\section{Research project: "Veterinary aspects of food safety and quality"}

This project is based on the comprehensive European concept of food safety. It has been methodologically divided into veterinary aspects of relevance to the following five areas: environmental conditions of raw foodstuff production; feed production and animal nutrition; animal production health, and animal protection and welfare; hygiene and food safety of products and foodstuffs; and veterinary protection of public health.

With regard to veterinary aspects of environmental conditions of raw foodstuff production, investigations are in progress into levels of contamination by selected organic pollutants and risk elements (Beklova et al. 2005, 2007; Penaz et al. 2005; Pikula et al. 2005a; Mikula and Svobodova 2006; Krizkova et al. 2007) and radionuclides (Dvorak et al. 2005, 2006a,b,c; Benova et al. 2007) in the environment. Some of the methodologies used for pollutant determination are also being investigated. In addition, the health status of some animal species occurring naturally in the environment used for feed production, animal rearing, and food production plants is also under investigation (Literak et al. 2005, 2006a,b; Pikula et al. 2005b; Bartova et al. 2006; Bochkov and Literak 2006; Hauptmanova et al. 2006a; Kopecna et al. 2006; Literak and Sitko 2006; Spitalska et al. 2006; Cizek et al. 2007).

In the area of veterinary aspects of feed production and animal nutrition, efforts are being made to identify suitable plant-based components to be substituted for animal-based components in feed mixes intended for laying hens, broilers, and pheasants, and also to test their efficacy. Research in this area particularly focuses on lupin (Lupinus) seed (Strakova et al. 2006a; Suchy et al. 2006b). Studies are also in progress to determine the possibility of supplementing poultry feed with clinoptilolites to increase performance and protect health (Suchy et al. 2006a). Other studies in this area include the effect of diet on the internal environment of animals and on aspects of the quality of products made from them (Večerek et al. 2005; Strakova et al. 2006b).

In the field of veterinary aspects of animal production health, and animal protection and welfare, the metabolism of animals intended for food, in relation to the quality and safety of animal products, is being investigated with particular emphasis on evaluating levels of selected substances in animal products intended for human consumption (Pechova et al. 2006a,b).

Phone: +420 541562770

Fax: +420541562790

E-mail: vecerekv@vfu.cz

http://www.vfu.cz/acta-vet/actavet.htm 
Studies of the effects of some types of animal housing on the quality of poultry production, the effect of diet on the performance and health of animals intended for food, and the effect of diet on the level of animal production health, as evaluated by haematological and biochemical parameters, have been completed (Hauptmanova et al. 2006b; Pistekova et al. 2006; Svobodova et al. 2006a; Voslarova et al. 2006a; Dvorak et al. 2007).

Embryo-larval toxicity tests and their utility have been evaluated with respect to fish production health. Toxicity tests were conducted in quails and fish to determine the toxicity of extracts prepared from cyanobacterial biomass. The effect of water blooms of cyanobacteria on amino acids and fatty acids has been studied in fish (Krejci and Palikova 2006; Palikova and Krejci 2006; Palikova et al. 2007; Skocovska et al. 2007).

Factors inducing stress in animals intended for food have also been studied. This research focused on stress indicators in animals intended for food. Other studies have dealt with the transport and pre-slaughter handling of animals. These have included the effects of travel distance and season on transport-induced mortality in fattened cattle, dairy cows, calves, pigs, broilers, and turkeys; the levels of stress in poultry and pheasants at different packing densities during transport, stress due to transport, transport-induced stress in fish (carps); and stress in poultry resulting from shackling before slaughter. Research results have been published by Bedanova et al. (2006, 2007a,b), Blahova et al. (2007), Dobsikova et al. (2006a), Malena et al. (2006), Suchy et al. (2007), Vecerek et al. (2006a,b,c,d), and Voslarova et al. (2006b,c, 2007).

Research on veterinary aspects of hygiene and safety of products and foodstuffs has focused on pathogenic microorganisms, particularly with respect to the collection, isolation, typing and identification of species and on antibiotic resistance. Studies of bacteria and food safety have included Campylobacter and Yersinia, as well as others, and their survival rates in connection with potential risks for food-borne diseases transmission. Research has also been conducted to identify the phenotype for resistance to antibacterial substances in selected isolates of pathogenic microorganisms, and has utilized PCR methods to detect the selected resistance-coding genes, and to monitor the occurrence of bacterial toxins in selected foods. These results have been published in papers by Cupakova et al. (2005), Kolackova and Karpiskova (2005), Nebola and Steinhauserova (2006), Steinhauserova et al. (2005, 2007), and Vazlerova and Steinhauserova (2006).

Within the evaluation of chemical parameters of food safety, levels of biogenic amines in selected commodities were assessed with regard to the conditions of food treatment in fish. Levels of selected substances in fish, meat products, and honey were assessed with respect to specific technological procedures, and oxidative processes were investigated in selected foodstuffs in research reported by Halamickova et al. (2006), Kordiovska et al. (2006), Marsalek and Svobodova (2006), Marsalek et al. (2005, 2006), Vorlova et al. (2005).

Additionally, chemical parameters indicating the quality of animal products (milk, honey) with regard to some technological processes were determined (Navratilova et al. 2006a,b; Vorlova et al. 2006). Quality parameters in meat from carp and tench hybrid lines under varying treatment conditions were assessed (Buchtova et al. 2005a,b, 2006a,b; Buchtova 2007). Proteolytic activity of B. cereus in milk was also studied (Janstova et al. 2006a,b).

Food adulteration assessment included the use of microscopy, histology and image analysis to demonstrate the presence of some of the components characteristic of food adulteration (Tremlova et al. 2006a,b).

Within the field of veterinary protection of public health, risks originating from the meat and organs of animals intended for food production were assessed and analysed, particularly from poultry (Celechovska et al. 2005; Mikulicova et al. 2005).

Risks to humans from the aquatic environment were defined with respect to possible effect on food safety and quality. The impact of certain contaminants in the aquatic environment on the health of fish was evaluated with respect to food safety. The effects 
of some pollutants in the aquatic environment were modelled experimentally in fish or evaluated by using embryo-larval toxicity tests (cypermethrin, deltamethrin, bisphenol A, 17-beta-estradiol, propylparaben, nitrites, chlorides). The results appeared in papers published by Drastichova et al. (2005), Pistekova et al. (2005), Svobodova et al. (2005, 2006b), Dobsikova et al. (2006b), Kroupova et al. (2006), Mikula et al. (2006), Velisek et al. (2006a,b, 2007), and Voslarova et al. (2006d).

\section{Research project: "Active enhancement of health, performance and utility of animals"}

The main aim of this project is to gain deeper insight into the modification of metabolism and reproductive capacities of ruminants, pigs, and horses with the intent of enhancing health, performance, and utility.

Research concerning the active enhancement of health and production performance in cattle and small ruminants investigated the effect of selenium and chromium metabolism on the internal environment of ruminants, the effect of diet in dairy cows and calves on production performance, and the diagnosis of certain diseases. Papers in this area were published by Gopfert et al. (2006), Komprda et al. (2005), Pavlata et al. (2005), Pechova and Pavlata (2007), Pechova et al. (2005), Zendulkova et al. (2007).

Research into the active enhancement of health and performance in pigs investigated the role of iron on health and production performance in pigs, particularly with respect to its absorption, metabolism, and utilization, and also its impact on immunity and the animal's internal environment. Papers addressing this topic were published particularly by Svoboda et al. (2005a,b,c, 2007) and Zelnickova et al. (2006).

Research concerning methods of improving health and increasing performance in horses, particularly investigated the relationship between selenium supplementation and the occurrence of myopathies in horses. Major diseases of the digestive system and the occurrence of some blood disorders in horses were also investigated. Papers in this area were published by Bezdekova et al. (2006, 2007), Jahn et al. (2006), Ludvikova et al. (2005a,b, 2007), Mezerova et al. (2006).

Research regarding enhancement of reproduction in ruminants, pigs and horses focused on methods that affect follicle development, ovulation, and in vivo and in vitro embryo production. This topic was addressed in papers by Hartman et al. (2006) and Lopatarova et al. (2006).

Research supported by these two projects at the University of Veterinary and Pharmaceutical Sciences in Brno is contributing to broadening scientific knowledge in the area of veterinary aspects of food safety and quality, and animal production health.

\section{References}

BARTOVA E, SEDLAK K, LITERAK I 2006: Prevalence of Toxoplasma gondii and Neospora caninum antibodies in wild boar (Sus scrofa) from the Czech Republic. Vet Parasitol 142: 150-153

BEDANOVA I, VOSLAROVA E, CHLOUPEK P, PISTEKOVA V, SUCHY P, BLAHOVA J, DOBSIKOVA R, VECEREK V 2007b: Stress in broilers resulting from shackling. Poult Sci 86: 1065-1069

BEDANOVA I, VOSLAROVA E, VECEREK V, PISTEKOVA V, CHLOUPEK P 2006: Effects of reduction in floor space during crating on haematological indices in broilers. Berliner Munchener Tierarztl Wochenschr 119: 17-21

BEDANOVA I, VOSLAROVA E, VECEREK V, PISTEKOVA V, CHLOUPEK P 2007a: Haematological profile of broiler chickens under acute stress due to shackling. Acta Vet. Brno 76: 129-135

BEKLOVA M, KRIZKOVA S, SUPALKOVA V, MIKELOVA R, ADAM V, PIKULA J, KIZEK R 2007: Determination of bromadiolone in pheasants and foxes by differential pulse voltammetry. Int J Environ Anal Chem 87: 459-469

BEKLOVA M, PIKULA J, HORAKOVA J, SKOCOVSKA B, VITULA F 2005: Evaluation of environmental hazards of rodenticides. Chem Listy 99: 79-81

BENOVA K, DVORAK P, FALIS M, SKLENAR Z 2007: Interaction of low doses of ionizing radiation, potassium dichromate and cadmium chloride in Artemia franciscana biotest. Acta Vet. Brno 76: 83-90 
BEZDEKOVA B, JAHN P, MEZEROVA J 2006: Pyloric ulceration and stenosis in two-year-old thoroughbred filly: a case report. Vet Med 51: 75-80

BEZDEKOVA B, JAHN P, VYSKOCIL M 2007: Pathomorphological study on gastroduodenal ulceration in horses: Localisation of lesions. Acta Vet. Hung 55: 241-249

BLAHOVA J, DOBSIKOVA R, SVOBODOVA Z, KALAB P 2007: Simultaneous determination of plasma cortisol by high performance liquid chromatography and radioimmunoassay methods in fish. Acta Vet Brno 76: $59-64$

BOCHKOV AV, LITERAK I 2006: A review of the European Harpirhynchidae (Acari, Prostigmata) with the description of a new species. Acta Parasitolog 51: 136-142

BUCHTOVA H, SMUTNA M, VORLOVA L, SVOBODOVA Z, FLAJSHANS M 2005a: Amino acid composition of muscle proteins of diploid and triploid tench (Tinca tinca, Linnaeus 1758). Acta Vet Brno 74: 329-337

BUCHTOVA H, SVOBODOVA Z, KOCOUR M, VELISEK J 2007: Amino acid composition of edible parts of three-year-old experimental scaly crossbreds of common carp (Cyprinus carpio, Linnaeus 1758). Aquac Res 38: $625-634$

BUCHTOVA H, SVOBODOVA Z, KOCOUR M, VELISEK J 2006a: Evaluation of growth and dressing out parameters of experimental scaly crossbreds in three-year-old common carp (Cyprinus carpio, Linnaeus 1758). Aquac Res 37: 466-471

BUCHTOVA H, SVOBODOVA Z, KOCOUR M, VELISEK J 2006b: Evaluation of the dressing percentage of 3-year-old experimental scaly crossbreds of the common carp (Cyprinus carpio, Linnaeus 1758) in relation to sex. Acta Vet Brno 75: 123-132

BUCHTOVA H, VORLOVA L, SVOBODOVA Z, FLAJSHANS M 2005b: Chemical composition of flesh of diploid and triploid population of tench (Tinca tinca, Linnaeus 1758). Czech J Anim Sci 50: 213-219

CELECHOVSKA O, SVOBODOVA Z, RANDAK T 2005: Arsenic content in tissues of fish from the river Elbe. Acta Vet Brno 74: 419-452

CIZEK A, DOLEJSKA M, KARPISKOVA R, DEDICOVA D, LITERAK I 2007: Wild black-headed gulls (Larus ridibundus) as an environmental reservoir of Salmonella strains resistant to antimicrobial drugs. Eur J Wildl Res 53: 55-60

CUPAKOVA S, POSPISILOVA M, KOLACKOVA I, KARPISKOVA R 2005: Genus-specific identification of enterococci by PCR method. Acta Vet. Brno 74: 633-637

DOBSIKOVA R, SVOBODOVA Z, BLAHOVA J, MODRA H, VELISEK J 2006a: Stress response to long distance transportation of common carp (Cyprinus carpio L.). Acta Vet. Brno 75: 437-448

DOBSIKOVA R, VELISEK J, WLASOW T, GOMULKA P, SVOBODOVA Z, NOVOTNY L 2006b: Effects of cypermethrin on some haematological, biochemical and histopathological parameters of common carp (Cyprinus carpio L.). Neuroendocrinol Lett 27 suppl. 2: 91-95

DRASTICHOVA J, SVOBODOVA Z, GROENLAND M, DOBSIKOVA R, ZLABEK V, WEISSOVA D, SZOTKOWSKA M 2005: Effect of exposure to bisphenol A and 17ß-estradiol on the sex differentiation in zebrafish (Danio rerio). Acta Vet. Brno 74: 287-291

DVORAK P, KUNOVA V, BENOVA K 2006b: Exponential drop of radiocesium activity in mushrooms due to the effect of acetic acid. Eur Food Res Technol 222: 139-143

DVORAK P, KUNOVA V, BENOVA K, OHERA M 2006a: Radiocesium in mushrooms from selected locations in the Czech Republic and the Slovak Republic. Radiat Environ Biophys 45: 145-151

DVORAK P, KUNOVA J, STRAKOVA E, SUCHY P, KUNOVA V 2005: Changes in the colour and the acidity number of egg yolk upon irradiation. Eur Food Res Technol 221: 348-350

DVORAK P, SALPLACHTA J, ZIMA S, GROLICHOVA M, MUSILOVA H 2006c: The effect of ionizing radiation on tissue enzymes. Bull Vet Inst Pulawy 50: 221 - 223

DVORAK P, STRAKOVA E, KUNOVA J, KUNOVA V 2007: Variation in egg yolk colour with the composition of the feeding mixture for laying hens. Acta Vet. Brno 76: 77-82

GOPFERT E, TRCKOVA M, DVORAK R 2006: The use of cured rapecake in a calf diet. Czech J Anim Sci 51: 491-501

HALAMICKOVAA, VORLOVA L, SMUTNA M, STRAKOVA E, SUCHY P, VECEREK V 2006: The effect of feed and temperature regiment on lipid oxidation in muscles of broiler chickens. Acta Vet. Brno 75: 39-48

HARTMAN P, ZAJIC J, CECH S, JAN Z, DOLEZEL R 2006: Replacement of the first GnRH administration in the ovsynch protocol by selecting cows according to the stage of follicular development. Acta Vet. Brno 75: 65-72

HAUPTMANOVA K, BENEDIKT V, LITERAK I 2006a: Blood parasites in passerine birds in Slovakian East Carpathians. Acta Protozool 45: 105-109

HAUPTMANOVA K, MALY M, LITERAK I 2006b: Changes of haematological parameters in common pheasant throughout the year. Vet Med 51: 29-34

JAHN P, DOUBEK J, DOUBEK M, BOUDA J 2006: Idiopathic thrombocytopenic purpura and anemia in a pregnant mare. Equine Vet Educ 18: 80-83

JANSTOVA B, DRACKOVA M, VORLOVA L 2006a: Effect of Bacillus cereus enzymes on milk quality following ultra high temperature-processing. Acta Vet Brno 75: 601-609

JANSTOVA B, VORLOVA L, DRACKOVA M 2006b: The effect of lipolytic enzymes of Bacillus spp. on quality of ultra-high-temperature-treated milk. Acta Vet. Brno 75: 427-435 
KOLACKOVAI, KARPISKOVA R 2005: Species level identification of thermotolerant campylobacters. Vet Med 50: 543-547

KOMPRDA T, DVORAK R, FIALOVA M, SUSTOVA K, PECHOVA A 2005: Fatty acid content in milk of dairy cows on a diet with high content derived from rapeseed. Czech J Anim Sci 50: 311-319

KOPECNA M, ONDRUS S, LITERAK I, KLIMES J, HORVATHOVA A, MORAVKOVA M, BARTOS M, TRCKA I, PAVLIK I 2006: Detection of Mycobacterium avium subsp. paratuberculosis in two brown bears in the Central European Carpathians. J Wildl Dis 42: 691-695

KORDIOVSKA L, VORLOVA L, BORKOVCOVA I, KARPISKOVA R, BUCHTOVA H, SVOBODOVA Z, KRIZEK M, VACHA F 2006: The dynamics of biogenic formation in muscle tissue of carp (Cyprinus carpio). Czech J Anim Sci 51: 262-270

KREJCI R, PALIKOVA M 2006: Potassium dichromate as a reference substance for embryonic tests of toxicity in the common carp (Cyprinus carpio L.). Acta Vet. Brno 75: 259-263

KRIZKOVA S, ZITKA O, ADAM V, BEKLOVA M, HORNA A, SVOBODOVA Z, SURES B, TRNKOVA L, ZEMAN L, KIZEK R 2007: Possibilities of electrochemical techniques in metallothionein and lead detection on fish tissues. Czech J Anim Sci 52: 143-148

KROUPOVA H, MACHOVA J, SVOBODOVA Z, PIACKOVA V, SMUTNA M 2006: The ability of recovery in common carp after nitrite poisoning. Vet Med 51: 423-431

LITERAK I, SITKO J 2006: Where in Europe should we look for sources of the cutaneous trematode Collyriclum faba infections in migrating birds' J Helminthol 80: 349-355

LITERAK I, SMID B, DUSBABEK F, HALOUZKA R, NOVOTNY L 2005: Co-infection with papillomavirus and Knemidokoptes jamaicensis (Acari: Knemidokoptidae) in a chaffinch (Fringilla coelebs) and a case of beak papillomatosis in another chaffinch. Vet Med 50: 276-280

LITERAK I, TENORA F, LETKOVA V, GOLDOVA M, TORRES J, OLSON PD 2006a: Mesocestoides litteratus (Batsch, 1786) (Cestoda: Cyclophyllidea: Mesocestoididae) from the red fox: morphological and 18S rDNA characterization of European isolates. Helminthologia 43: 191-195

LITERAK I, TOMITA Y, OGAWA T, SHIRASAWA H, SMID B, NOVOTNY L, ADAMEC M 2006b: Papillomatosis in a European Bison. J Wildl Dis 42: 149-153

LOPATAROVA M, CECH S, HOLY L, DOLEZEL R 2006: The effect of vitrification in open pulled straws on pregnancy rates after transfer of in vivo produced bovine embryo. Vet Med 51: 454-460

LUDVIKOVA E, JAHN P, LUKAS Z 2007: Nutritional myodegeneration as a cause of dysphagia in adult horses. Vet Med 52: 267-272

LUDVIKOVA E, JAHN P, PAVLATA L, VYSKOCIL M 2005b: Selenium and vitamin E status correlated with myopathies of horses reared in farms in the Czech Republic. Acta Vet. Brno 74: 377-384

LUDVIKOVA E, PAVLATA L, VYSKOCIL M, JAHN P 2005a: Selenium status of horses in the Czech Republic. Acta Vet. Brno 74: 369-375

MALENA M, VOSLAROVA E, TOMANOVA P, LEPKOVA R, BEDANOVA I, VECEREK V 2006: Influence of travel distance and the season upon transport-induced mortality in fattened cattle. Acta Vet. Brno 75: 619-624

MARSALEK P, SVOBODOVA Z 2006: Rapid determination of methylmercury in fish tissues. Czech J Food Sci 24: $138-142$

MARSALEK P, SVOBODOVA Z, RANDAK T 2006: Total mercury and methylmercury contamination in fish from various sites along the Elbe River. Acta Vet. Brno 75: 579-586.

MARSALEK P, SVOBODOVA Z, RANDAK T, SVEHLA J 2005: Mercury and methylmercury contamination of fish from the Skalka reservoir: A case study. Acta Vet. Brno 74: 427-434

MEZEROVA J, KOUDELA B, VOJTKOVA M 2006: Kolikerkrankungen des Pferdes in Zusammenhang mit Bandwurmbefall - 5 klinische Fallberichte. Prakt Tierarzt 88: 26-33

MIKULA P, DOBSIKOVA R, SVOBODOVA Z, JARKOVSKY J 2006: Evaluation of xenoestrogenic potential of propylparaben in zebrafish (Danio rerio). Neuroendocrinol Lett 27 suppl. 2: 104-107

MIKULA P, SVOBODOVA Z 2006: Brominated flame retardants in the environment: their sources and effects (review). Acta Vet. Brno 75: 587-600

MIKULICOVA M, STEINHAUSEROVA I, BORILOVA G, NEBOLA M 2005: Antimicrobial susceptibility of $C$. jejuji and C. coli strains isolated from poultry and pigs in the Czech Republic. Acta Vet Brno 74: 639-644

NAVRATILOVA P, HADRA L, DRACKOVA M, JANSTOVA B, VORLOVA L, PAVLATA L 2006a: Use of FTNIR spectroscopy for bovine colostrum analysis. Acta Vet. Brno 75: 57-63

NAVRATILOVA P, JANSTOVA B, GLOSSOVA P, VORLOVA L 2006b: Freezing Point of heat-treated drinking milk in the Czech Republic. Czech J Food Sci 24: 156-163

NEBOLA M, STEINHAUSEROVA I 2006: PFGE and PCR/RFLP typing of Campylobacter jejuni strains from poultry. Br Poult Sci 47: 456-461

PALIKOVA M, KREJCI R 2006: Artificial stripping and embryonic development of the common gudgeon (Gobio gobio L.) and its use in embryo-larval tests - a pilot study. Czech J Anim Sci 51: 174-180

PALIKOVA M, KREJCI R, HILSCHEROVA K, BURYSKOVA B, BABICA P, NAVRATIL S, KOPP R, BLAHA L 2007: Effect of different cyanobacterial biomasses and their fractions with variable microcystin content on embryonal development of carp (Cyprinus carpio L.). Aquat Toxicol 81: 312-318

PAVLATA L, SLOSARKOVA S, FLEISCHER P, PECHOVA A 2005: Effects of increased iodine supply on the selenium status of kids. Vet Med 50: 186-194 
PECHOVAA, DVORAK R, DRASTICH P, LUBOJACKA V, PAVLATA L, POUL J 2006a: Influence of increased lipid content in diet in the form of treated rapeseed meal on the metabolism and milk yield of dairy cows in the first third of lactation. Vet Med 51: 346-355

PECHOVA A, PAVLATA L 2007: Chromium as an essential nutrient: a review. Vet Med 52: 1-18

PECHOVA A, PAVLATA L, ILLEK J 2005: Blood and tissue selenium determination by hydride generation atomic absorption spectrophotometry. Acta Vet. Brno 74: 483-490

PECHOVA A, PAVLATA L, LOKAJOVA E 2006b: Zinc supplementation and somatic cell count in milk of dairy cows. Acta Vet. Brno 75: 361-367

PENAZ M, SVOBODOVA Z, BARUS V, PROKES M, DRASTICHOVA J 2005: Endocrine disruption in barbel, Barbus barbus population from the river Jihlava, Czech Republic. J Appl Ichthyol 21: 420-428

PIKULA J, BEKLOVA M, HORAKOVA J, SKOCOVSKA B, VITULA F 2005a: Comparation of toxic effects of rodenticides for birds. Chem Listy 99: 77-79

PIKULA J, BEKLOVA M, HOLESOVSKA Z, SKOCOVSKA B, TREML F 2005b: Ecology of brucellosis of the European hare in the Czech Republic. Vet Med 50: 105-109

PISTEKOVA V, HOVORKA M, VECEREK V, STRAKOVA E, SUCHY P 2006: The quality comparison of eggs laid by laying hens kept in battery cages and in a deep litter system. Czech J Anim Sci 51: 318-325

PISTEKOVA V, VOSLAROVA E, SVOBODOVA Z 2005: Nitrite toxicity to Danio rerio: effects of chloride concentrations during acclimatization and in toxicity tests. Acta Vet. Brno 74: 435-440

SKOCOVSKA B, HILSCHEROVA K, BABICA P, ADAMOVSKY O, BANDOUCHOVA H, HORAKOVA J, KNOTKOVA Z, MARSALEK B, PASKOVA V, PIKULA J 2007: Effects of cyanobacterial biomass on the Japanese quail. Toxicon 49: 793-803

SPITALSKA E, LITERAK I, SPARAGANO OAE, GOLOVCHENKO M, KOCIANOVA E 2006: Ticks (Ixodidae) from passerine birds in the Carpathian region. Wien Klin Wochen 118: 759-764

STEINHAUSEROVA I, NEBOLA M, MIKULICOVA M 2005: Prevalence of thermophilic Campylobacter spp. in slaughtered pigs in the Czech Republic 2001-2003. Vet Med 50: 171-174

STEINHAUSEROVA I, NEBOLA M, MIKULICOVA M 2007: Thermophilous classes of Campylobacter spp. in pigs. Fleischwirtschaft 87: 89-91

STRAKOVA E, SUCHY P, VECEREK V, SERMAN V, MAS N, JUZL M 2006a: Nutritional composition of seeds of the Lupinus family. Acta Vet. Brno 75: 489-494

STRAKOVA E, SUCHY P, VITULA F, VECEREK V 2006b: Differences in the amino acid composition of muscles from pheasant and broiler chickens. Arch Tierz-Arch Anim Breed 49: 508-514

SUCHY P, BEDANOVA I, VECEREK V, VOSLAROVA E, PISTEKOVA V, CHLOUPEK P, VITULA F 2007: Effects of transport stress and floor space reduction on selected biochemical indices in common pheasant (Phasianus colchicus). Arch Geflugelkd 71: 56-61

SUCHY P, STRAKOVA E, VECEREK V, KLOUDA Z, KRACMAROVA E 2006a: The effect of a clinoptilolite - based feed supplement on the performance of broiler chickens. Czech J Anim Sci 51: 168-173

SUCHY P, STRAKOVA E, VECEREK V, SERMAN V, MAS N 2006b: Testing of two varieties of lupin seeds as substitutes for soya extracted meal in vegetable diets designed for young broilers. Acta Vet Brno 75 : 495-500

SVOBODA M, BOUDA J, KRAJCEK M, DRABEK J, DOUBEK J, KOTRBACEK V 2005a: Effect of voluntary consumption of Fe lactate supplements on development of haematological indices of suckling piglets. Acta Vet. Bmo 74: 199-204

SVOBODA M, DRABEK J, FICEK R 2005c: Effect of bovine lactoferrin on utilization of orally administered iron in suckling piglets. Bull Vet Inst Pulawy 49: 471-474

SVOBODA M, EICHLEROVA K, HORAK V, HRADECKY J 2005b: Development of haematological indices in melanoma-bearing Liběchov minipigs. Acta Vet. Brno 74: 603-611

SVOBODA M, NECHVATALOVA K, KREJCI J, DRABEK J, FICEK R 2007: Effect of iron deficiency on humoral immune response of piglets against tetanus toxoid. Vet Med 52: 179-185

SVOBODOVA Z, MACHOVA J, DRASTICHOVA J, GROCH K, LUSKOVA V, POLESZCZUK G, VELISEK J, KROUPOVA H 2005: Haematological and biochemical profiles of carp blood following nitrite exposure at different concentrations of chloride. Aquac Res 36: 1177-1184

SVOBODOVA Z, SUDOVA E, NEPEJCHALOVA L, VYKUSOVA B, MODRA H, KOLAROVA J, CERVINKA S 2006b: Effects of oxytetracycline containing feed on pond ecosystem and health of carp (Cyprinus carpio L.). Acta Vet. Brno 75: 571-578

SVOBODOVA Z, VYKUSOVA B, MODRA H, JARKOVSKY J, SMUTNA M 2006a: Haematological and biochemical profile of harvest - size carp during harvest and relaying. Aquac Res 37: 959-965

TREMLOVA B, STARHA P, BUNKA F, GISTINGROVA Z, HRABE J 2006a: The effect of sterilization on size and shape of fat globules in model processed cheese samples. Acta Vet Brno 75: 419-425

TREMLOVA B, STARHA P, POSPIECH M, BUCHTOVA H, RANDULOVA Z 2006b: Histological analysis of different kinds of mechanically recovered meat. Arch Lebensm hyg 57: 85-91

VAZLEROVA M, STEINHAUSEROVA I 2006: The comparison of the methods for the identification of pathogenic serotypes and biotypes of Yersinia enterocolitica: Microbiological methods and PCR. Czech J Anim Sci 24: 217-222 
VECEREK V, GRBALOVA S, VOSLAROVA E, JANACKOVA B, MALENA M 2006a: Effects of travel distance and the season of the year on death rates of broilers transported to poultry processing plants. Poult Sci 85: $1881-1884$

VECEREK V, MALENA M jr, MALENA M, VOSLAROVA E, BEDANOVA I 2006b: Mortality in dairy cows transported to slaughter as affected by travel distance and seasonality. Acta Vet. Brno 75: 449-454

VECEREK V, MALENA M, MALENA M jr, VOSLAROVA E, CHLOUPEK P 2006c: The impact of the transport distance and season on losses of fattened pigs during transport to the slaughterhouse in the Czech Republic in the period from 1997 to 2004. Vet Med 51: 21-28

VECEREK V, SIMOVA V, MALENA M, VOSLAROVA E, MALENA M jr 2006d: Effect of calf diseases on mortality during transport for slaughter. Acta Vet. Brno 75: 625-630

VECEREK V, SUCHY P, STRAKOVA E, VITULA F, MIKUNDOVA M 2005: Variation in the chemical composition of muscles in young pheasants during their growth. Arch Tierz-Arch Anim Breed 48: 290-298

VELISEK V, DOBSIKOVA R, SVOBODOVA Z, MODRA H, LUSKOVA V 2006b: Effect of deltamethrin on the biochemical profile of common carp (Cyprinus carpio L.). Bull Environ Contam Toxicol 76: 992-998

VELISEK J, JURCIKOVA J, DOBSIKOVA R, SVOBODOVA Z, PIACKOVA V, MACHOVA J, NOVOTNY L 2007: Effects of deltamethrin on rainbow trout (Oncorhynchus mykiss). Environ Toxicol Pharmacol 23: $297-$ 301

VELISEK J, WLASOW T, GOMULKA P, SVOBODOVA Z, DOBSIKOVA R, NOVOTNY L, DUDZIK M 2006a: Effects of cypermethrin on rainbow trout (Onchorhynchus mykiss). Vet Med 10: 469-476

VORLOVA L, BORKOVCOVA I, KALABOVA K, VECEREK V 2006: Hydroxymethylfurfural contents in foodstuffs determined by HPLC method. J Food Nutr Res 45: 34-38

VORLOVA L, KARPISKOVA R, CHABINIOKOVA I, KALABOVA K, BRAZDOVA Z 2005: The antimicrobial activity of honeys produced in the Czech Republic. Czech J Anim Sci 50: 376-384

VOSLAROVA E, BEDANOVA I, VECEREK V, PISTEKOVA V, CHLOUPEK P, SUCHY P 2006b: Changes in haematological profile of common pheasant (Phasianus colchicus) induced by transit to pheasantry. Dtsch Tierarztl Wochenschr 113: 375-378

VOSLAROVA E, HANZALEK Z, VECEREK V, STRAKOVA E, SUCHY P 2006a: Comparison between laying hen performance in the cage system and the deep litter system on a diet free from animal protein. Acta Vet. Brno 75: 219-225

VOSLAROVA E, JANACKOVA B, VITULA F, KOZAK A, VECEREK V 2007: Effects of transport distance and the season of the year on death rates among hens and roosters in transport to poultry processing plants in the Czech Republic in the period from 1997 to 2004. Vet Med 52: 262-266

VOSLAROVA E, PISTEKOVA V, SVOBODOVA Z 2006d: Nitrite toxicity to Danio rerio: Effects of fish age and chloride concentrations. Acta Vet. Brno 75: 107-113

VOSLAROVA E, RUBESOVA L, VECEREK V, PISTEKOVA V, MALENA M 2006c: Variation in the mortality rate of turkeys during transport to the slaughterhouse with travel distance and month. Berliner Munchener Tierarztl Wochenschr 119: 386-390

ZELNICKOVA P, KOVARU H, PESAK S, LOJEK A, MATALOVA E, ONDRACEK J, KOVARU F 2006 : Postnatal functional maturation of blood phagocytes in pig. Vet Immunol Immunopathol 113: 383-391

ZENDULKOVA D, MADANAT A, LANY P, ROSENBERGROVA K, POSPISIL Z 2007: Detection of Mycoplasma agalactiae by polymerase chain reaction in Jordanian sheep and goats herds. Acta Vet. Brno 76: 71-77 